\title{
HEART RATE RESPONSES TO A MUSCARINIC AGONIST IN RATS WITH EXPERIMENTALLY INDUCED ACUTE AND SUBACUTE CHAGASIC MYOCARDITIS
}

\author{
Argenis TORRES(1), Diego F. DÁvilA(2), Carlos F. GOTTBERG(3), Jose H. DONIS(2), Gabriela ARATA DE BELLABARBA(1) \& Paolo RAMONI-PERAZZI(3)
}

\begin{abstract}
SUMMARY
We administered arecoline to rats, with experimentally induced chagasic myocarditis, in order to study the sinus node sensitivity to a muscarinic agonist. Sixteen month old rats were inoculated with 200,000 T. cruzi parasites ("Y" strain). Between days 18 and 21 (acute stage), 8 infected rats and 8 age-matched controls received intravenous arecoline as a bolus injection at the following doses: $5.0,10.0,20.0,40.0$, and $80.0 \mu \mathrm{g} / \mathrm{kg}$. Heart rate was recorded before, during and after each dose of arecoline. The remaining 8 infected animals and 8 controls were subjected to the same experimental procedure during the subacute stage, i.e., days 60 to 70 after inoculation. The baseline heart rate, of the animals studied during the acute stage ( $349 \pm 68 \mathrm{bpm}$, mean \pm SD), was higher than that of the controls $(250 \pm 50 \mathrm{bpm}, \mathrm{p}<0.005)$. The heart rate changes were expressed as percentage changes over baseline values. A doseresponse curve was constructed for each group of animals. Log scales were used to plot the systematically doubled doses of arecoline and the induced-heart rate changes. The slope of the regression line for the acutely infected animals $(r=-0.99, b=1.78)$ was not different from that for the control animals $(r=-0.97, b=1.61)$. The infected animals studied during the subacute stage $(r=-0.99, b$ $=1.81)$ were also not different from the age-matched controls $(r=-0.99, b=1.26, \mathrm{NS})$. Consequently, our results show no pharmacological evidence of postjunctional hypersensitivity to the muscarinic agonist arecoline. Therefore, these results indirectly suggest that the postganglionic parasympathetic innervation, of the sinus node of rats with autopsy proved chagasic myocarditis, is not irreversibly damaged by Trypanosoma cruzi.
\end{abstract}

KEYWORDS: Arecoline; Chagas`' disease; Muscarinic agonist; Muscarinic receptor; T. cruzi; Parasympathetic.

\section{INTRODUCTION}

The effects of experimentally induced chagasic myocarditis, on postganglionic-cardiac parasympathethic innervation, are still the subject of intense controversy ${ }^{12,13,21,36,38}$. Early studies showed morphologic abnormalities considered to be specifically and irreversibly caused by Trypanosoma $\mathrm{cruzi}^{26,36}$. However, more recent studies have found that, despite an obvious inflammatory response in the cardiac ganglia, the parasympathetic neurons were preserved from the infective process ${ }^{8,9,15,28}$.

Selective postganglionic parasympathetic denervation of the sinus node provokes postjunctional hypersensitivity to acetylcholine ${ }^{23}$. This denervation hypersensitivity is very likely due to an increase in the number of postsynaptic muscarinic receptors ${ }^{10,24}$. Consequently, if the cardiac parasympathetic neurons are primarily and irreversibly damaged by Trypanosoma cruzi-induced myocarditis, there should be pharmacological evidence of postjunctional hypersensitivity to a muscarinic agonist ${ }^{19,33,34}$. Therefore, in the present investigation, we have tested the hypothesis that, based on the Neurogenic Theory ${ }^{26}$ on the pathogenesis of Chagas'disease; the heart rate responses to a muscarinic agonist, as represented by the dose-response curves to arecoline of T. cruzi-infected animals, should be significantly different from those of normal controls ${ }^{19}$.

\section{MATERIAL AND METHODS}

Thirty-two 4-month old Wistar rats were separated in two groups. Sixteen rats were inoculated intraperitoneally with 200,000 T. cruzi parasites ("Y" strain) and 16 were used as controls". Between days 18 and 21 after inoculation (acute stage) $)^{4,11,35}, 8$ infected animals and 8 controls were anesthetized with intraperitoneal injection of urethane (Sigma, $1.25 \mathrm{~g} / \mathrm{kg}$ ). The animals breathed trough tracheal cannulation. A femoral vein was also cannulated. Rectal temperature was maintained at $37 \pm 0.5{ }^{\circ} \mathrm{C}$. Heart rate was recorded with a Grass 7 polygraph using standard limb leads. The paper speed was $50 \mathrm{~mm} / \mathrm{sec}$.

The heart rate response to intravenous administration of a muscarinic agonist was studied as follows: the animals were allowed to stabilize for 30 min and arecoline (Sigma) was administered intravenously as a bolus ${ }^{16}$. The following doses were used: 5.0, 10.0, 20.0, 40.0, and $80.0(\mu \mathrm{g} / \mathrm{kg})$.

Supported in part by CDCHT-ULA ( ${ }^{\circ}$ M-354-90 and C-534-91)

(1) Departamento de Fisiopatologia, Universidad de Los Andes, Mérida, Venezuela.

(2) Centro de Investigaciones Cardiovasculares, Universidad de Los Andes, Mérida, Venezuela.

(3) Departamento de Biología, Universidad de Los Andes. Mérida, Venezuela.

Correspondence to: Diego F. Dávila MD, Ph.D. Apartado Postal 590, Centro de Investigaciones Cardiovasculares, Mérida 5101 Venezuela. E-mail: diegod@ing.ula.ve 


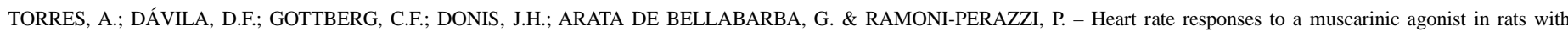
experimentally induced acute and subacute chagasic myocarditis. Rev. Inst. Med. trop. S. Paulo, 42(4): 219-224, 2000.

The solution was prepared immediately before each experiment. The electrocardiogram was recorded before, during and after each dose of arecoline. At the end of the experiment, the animals were sacrifized for cardiac histologic studies. The remaining 8 infected animals and 8 controls were subjected to the same experimental procedure between days 60 and 70 after inoculation (subacute stage).

\section{Statistical analysis}

The negative chronotropic response to arecoline was obtained by substracting the shortest P-P interval observed immediately before each bolus of arecoline from the longest P-P interval measured after each bolus of arecoline. Control and infected animals were compared by analysis of variance. A dose-response curve was constructed for each group of animals ${ }^{20}$.

Log scales were used to plot the systematically doubled doses of arecoline and the induced-heart rate changes.

\section{RESULTS}

\section{Acute stage}

The baseline heart rate of the infected animals (mean \pm SD, $349 \pm$ $68 \mathrm{bpm}$ ) was significantly higher than that of the noninfected controls $(250 \pm 50 \mathrm{bpm}, \mathrm{p}<0.005)$. Intravenous administration of arecoline provoked a dose-dependent decrease in heart rate. The negative chronotropic responses of both groups of animals were expressed as percentage changes over baseline values, to correct for the higher heart rate of the infected animals. Plotting of the two variables used in the study showed that they were linearly related. The slope of the regression line of the infected animals $(r=-0.99, b=1.78)$ was not significantly different from that of the age-matched noninfected controls $(r=-0.97, b$ = 1.61) (Table 1 and Fig. 1$)$.

Table 1

Heart rate responses to arecoline in the acute stage of chagasic myocarditis

\begin{tabular}{|c|c|c|c|c|c|}
\hline \multirow[b]{2}{*}{$\begin{array}{c}\text { Doses } \\
\text { Arecoline }(\mu / g r)\end{array}$} & \multicolumn{2}{|c|}{ Infected } & \multicolumn{2}{|c|}{ Control } & \multirow[b]{2}{*}{$\mathrm{p}$} \\
\hline & $\begin{array}{l}\text { Heart rate } \\
\text { (Beats/min) }\end{array}$ & $\begin{array}{c}\text { Percentage } \\
(\%)\end{array}$ & $\begin{array}{l}\text { Heart rate } \\
\text { (Beats/min) }\end{array}$ & $\begin{array}{c}\text { Percentage } \\
(\%)\end{array}$ & \\
\hline 5 & 0 & 0 & 0 & 0 & \\
\hline 10 & $-2.37 \pm 6.71$ & -1.02 & 0 & 0 & ns \\
\hline 20 & $-9.87 \pm 14.5$ & -2.5 & $-6.75 \pm 11.3$ & -2.38 & ns \\
\hline 40 & $-36.3 \pm 39.7$ & -7.96 & $-15.1 \pm 16.8$ & -4.83 & ns \\
\hline 80 & $-103 \pm 109$ & -24.74 & $-71 \pm 65$ & -19.31 & ns \\
\hline
\end{tabular}

Values are Mean \pm Standard Error

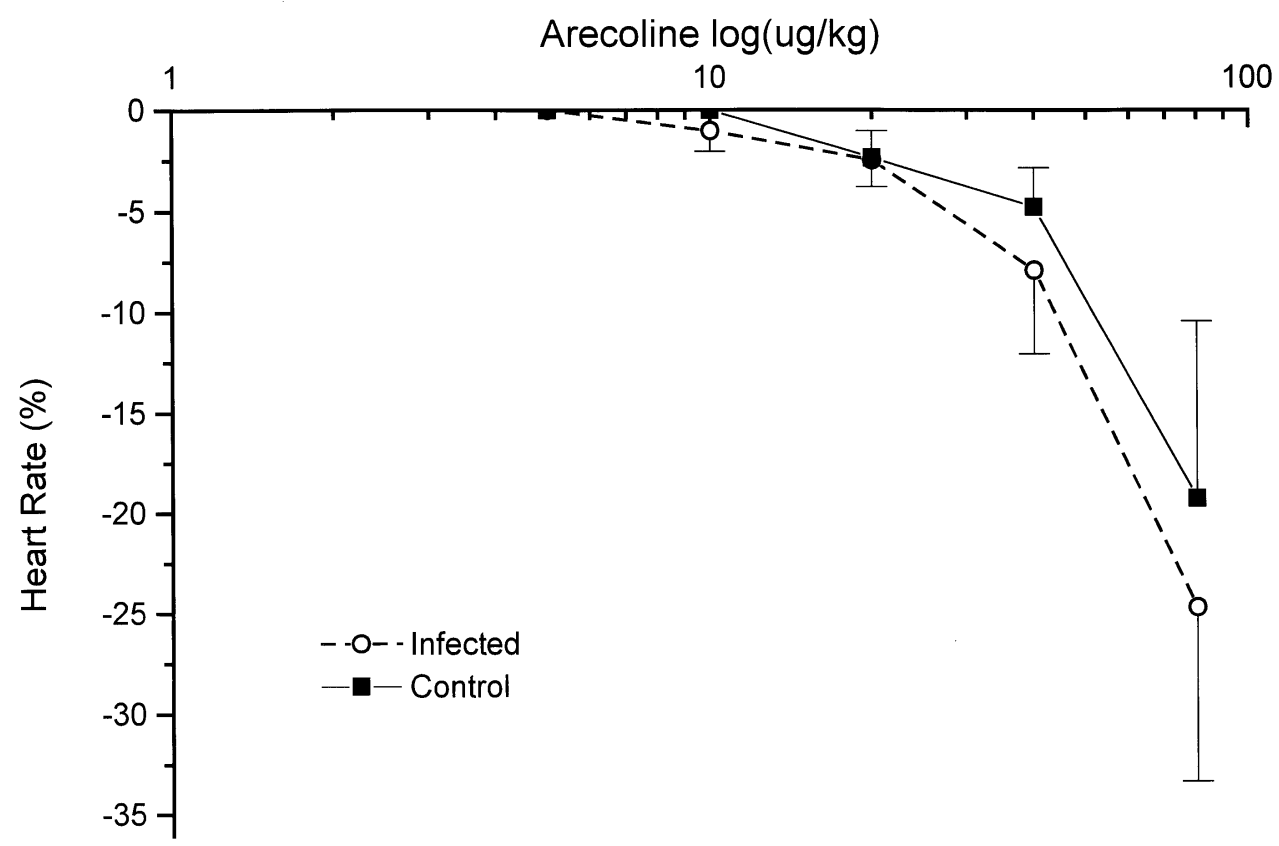

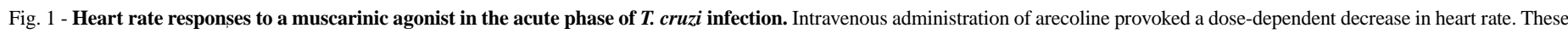

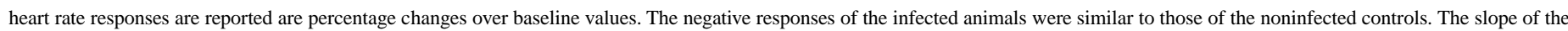
regression line of the infected animals $(r=-0.99, b=1.78)$ was not significantly different from that of the age-matched noninfected controls $(r=-0.97, b=1.61)$. 


\section{Subacute stage}

The baseline heart rate of infected animals $(304 \pm 25 \mathrm{bpm}$, Mean + SD) studied 60 to 70 days after inoculation was, although lower than that of the infected animals studied during the acute stage, still significantly higher than that of the noninfected age-matched controls $(254 \pm 28 \mathrm{bpm}$, $\mathrm{p}<0.001)$. The slope of the regression line for the infected animals $(r=-$ $0.99, b=1.81)$ was also similar to that of the age-matched noninfected controls $(r=-0.99, b=1.26$, NS) (Table 2 and Fig. 2).

\section{Histologic findings}

The control animals had no cardiac abnormalities, whereas the infected animals had variable degrees of diffuse myocarditis. Parasites were present in the hearts of all infected animals (acute stage). The hearts of the animals sacrificed between days 60 and 70 (subacute stage) were not examined.

\section{DISCUSSION}

Vagal preganglionic pathways controlling sinus node automaticity arise from the nucleus ambiguous of the medulla oblongata. These preganglionic fibers synapse with intracardiac postganglionic neurons, which are located in distinct anatomic regions of the heart ${ }^{27}$. In rats, postganglionic neurons are preferentially located in the atria and between the vena cava and the aortic $\operatorname{arch}^{31}$. In most mammals, postganglionic cholinesterase pathways to the sinus node arise from the atria and course subepicardially towards the sinus node ${ }^{2,6}$. These pathways are anatomically and functionally different from those mediating atrioventricular conduction and contractility changes ${ }^{5,30}$.

Table 2

Heart rate responses to arecoline in the subacute stage of chagasic myocarditis

\begin{tabular}{|c|c|c|c|c|c|}
\hline \multirow[b]{2}{*}{$\begin{array}{c}\text { Doses } \\
\text { Arecoline }(\mu / \mathrm{gr})\end{array}$} & \multicolumn{2}{|c|}{ Infected } & \multicolumn{2}{|c|}{ Control } & \multirow[b]{2}{*}{$\mathrm{p}$} \\
\hline & $\begin{array}{l}\text { Heart rate } \\
\text { (Beats/min) }\end{array}$ & $\begin{array}{l}\text { Percentage } \\
(\%)\end{array}$ & $\begin{array}{l}\text { Heart rate } \\
\text { (Beats/min) }\end{array}$ & $\begin{array}{l}\text { Percentage } \\
(\%)\end{array}$ & \\
\hline 5 & $-1 \pm 2.8$ & -0.33 & $-4.12 \pm 11.66$ & -1.23 & $\mathrm{~ns}$ \\
\hline 10 & $-3.5 \pm 9.8$ & -1.14 & $-8.58 \pm 16.5$ & -3.3 & $\mathrm{~ns}$ \\
\hline 20 & $-8.25 \pm 11.1$ & -2.51 & $-20.5 \pm 38.4$ & -7.12 & $\mathrm{~ns}$ \\
\hline 40 & $-37.12 \pm 52.4$ & -10.6 & $-41 \pm 38$ & -7.44 & ns \\
\hline 80 & $-169.2 \pm 102.1$ & -43.03 & $-154.6 \pm 127.2$ & -43.01 & $\mathrm{~ns}$ \\
\hline
\end{tabular}

Values are Mean \pm Standard Error

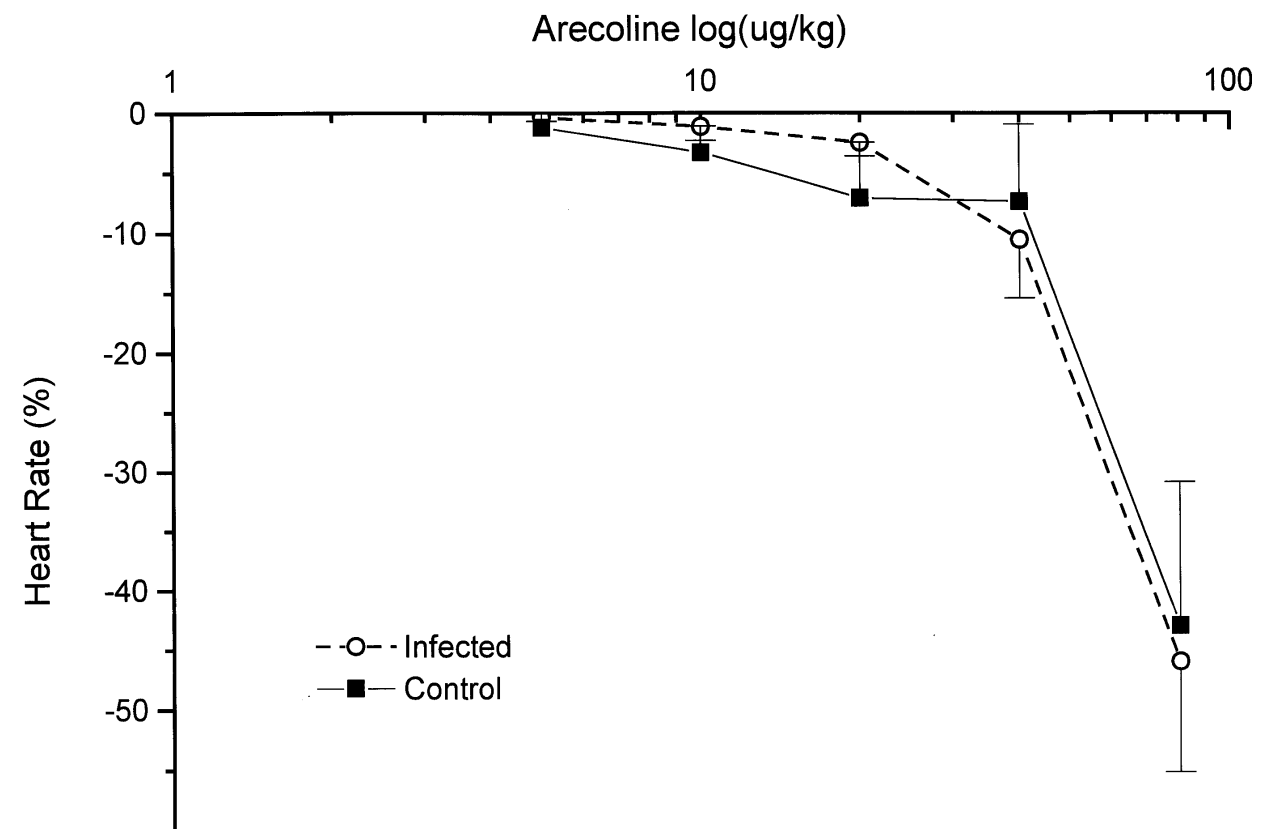

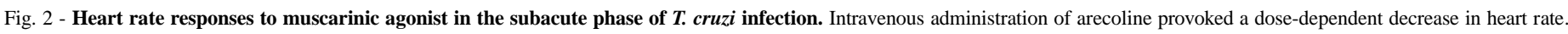

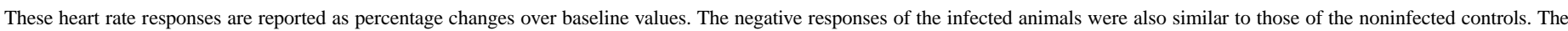
slope of the regression line of the infected animals $(r=-0.99, b=1.81)$ was not significantly different from that of the age-matched noninfected controls $(r=-0.99$, $b=1.26)$. 


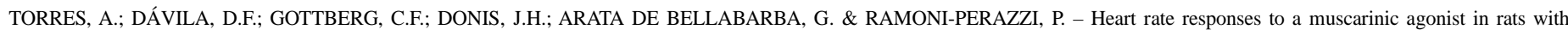
experimentally induced acute and subacute chagasic myocarditis. Rev. Inst. Med. trop. S. Paulo, 42(4): 219-224, 2000.

In experimentally induced chagasic myocarditis, parasite location and histological evidence of myocarditis are most prominent in the atria $^{35,36}$. Therefore, the already described anatomical location and functional differentiation of the vagal postganglionic innervation, of the sinus node, render these neural structures particularly vulnerable to Trypanosoma cruzi-induced myocarditis ${ }^{35,36}$.

According to the Neurogenic Theory, on the pathogenesis of human chagasic heart disease, the postganglionic vagal pathways to the sinus node are selectively and irreversibly damaged by Trypanosoma cruzi, during the acute stages of the disease. Myocardial damage, progressive cardiac dysfunction and death would be due to attenuation of parasympathetic influences on the sinus node and to an early and permanent activation of the cardiac sympathetic nervous system ${ }^{26}$. Therefore, in the present investigation, we have tested the hypothesis that, based on this theory, rats with experimentally induced acute and subacute chagasic myocarditis should have pharmacological evidence of postganglionic parasympathetic denervation of the sinus node. In other words, these laboratory animals should have postjunctional supersensitivity to the administration of a muscarinic agonist ${ }^{10,19,23,24,33}$. We found that the basal heart rate of the infected animals, studied during the acute and subacute stages, was significantly higher than that of the control animals. A higher basal heart rate may be secondary to an increase in cardiac sympathetic activity or to a decrease in cardiac vagal tone ${ }^{27}$. In laboratory animals, with experimentally induced chagasic myocarditis, sinus tachycardia is a distinct finding ${ }^{12,13,21}$. This sinus tachycardia, usually a compensatory phenomenon, is secondary to the acute inflammatory process and to a transiently enhanced background sympathetic activity ${ }^{13,35}$. An alternative explanation would be a primary and permanent damage to the cholinergic pathways to the sinus node ${ }^{28,36}$. However, the results of the present investigation showed that, the dose-response curves to arecoline of the infected animals studied during the acute and subacute stages of chagasic myocarditis, are not significantly different from those of normal controls. Therefore, these results indirectly suggest that the muscarinic receptors of the sinus node are not increased, in these laboratory animals with experimentally induced chagasic myocarditis.

Acetylcholine receptors in the nervous system can be studied using various techniques ${ }^{22}$. Denervation of cardiac muscle and of skeletal muscle is followed, within days by pharmacological and histochemical evidence of postganglionic hypersensitivity to acetylcholine $\mathrm{e}^{18,19,24,33}$. Nicotinic receptors in skeletal muscle and muscarinic receptors in brain tissue increase following inoculation of Trypanosoma cruzi. Cardiac muscarinic receptors, however, remain similar to controls ${ }^{37}$. Moreover, in vitro studies, which compared reticulotropic against myotropic strains of Trypanosoma cruzi, have also failed to show hypersensitivity of atrial tissue, of infected animals, to acetylcholine ${ }^{32}$.

The results of the present pharmacological investigation and very recent morphological ${ }^{28,39}$ and functional studies ${ }^{12,38}$ strongly argue against the presence of primary and irreversible damage to the cardiac parasympathetic neurons and cholinergic pathways, in rats with Trypanosoma cruzi-induced myocarditis. It should be pointed out that, in the present investigation, morphological studies were exclusively aimed at demonstrating the presence of the parasite in the myocardium of the infected animals (acute stage). The hearts of the infected animals studies between days 60 and 70 post infection (subacute stage) were not examined. In other words, the cardiac parasympathetic neurons were neither counted nor specifically examined. Consequently, we cannot rule out the presence or absence of morphological abnormalities of the cardiac parasympathetic neurons. Nonetheless, very recent experimental studies, carried out in different animal species, have found that despite an obvious inflammatory response in the cardiac ganglia, the parasympathetic neurons were preserved from the infective process and their number was not significantly diminished $8,9,11,15,28,39$.

As stated earlier, the Neurogenic Theory, on the pathogenesis of human chagasic heart disease, postulated that myocardial damage was secondary to a selective cardiac parasympathetic denervation and to an early activation of the cardiac sympathetic nervous system ${ }^{26}$. However, recent biochemical and functional studies in humans ${ }^{14,29}$ have failed to demonstrate the presence of attenuation of parasympathetic influences on the sinus node and of progressive activation of the sympathetic nervous system, in asymptomatic chagasic individuals, who had cineangiographic evidence of localized myocardial damage. On the contrary, symptomatic chagasic patients with advanced and diffuse myocardial damage have definitive evidence of attenuation of cardiac parasympathetic influences on the sinus node and of progressive and unopposed cardiac sympathetic activation $^{3,14}$. It should be emphasized that, these late autonomic abnormalities, are seen in most patients with cardiac disease and are not related to the underlying cause of the disease ${ }^{17}$. Furthermore, chagasic patients do benefit from drugs which antagonize sympathetic activation. Symptoms of congestive heart failure are improved and mortality is diminished, when neurohormonal activation is antagonized ${ }^{1,25}$. In other words, persistent and unopposed cardiac sympathetic activation, as postulated by the Neurogenic Theory, is partially responsible for the relentless progression of cardiac dysfunction of patients with Chagas' heart disease. Nonetheless, additional clinical and experimental research is needed to determine why do these autonomic abnormalities appear, in patients who have cardiac disease due to Chagas' disease?

In summary, the heart rate responses to the muscarinic agonist arecoline, of laboratory animals with acute and subacute and chagasic myocarditis, indirectly suggest that the muscarinic receptors of the sinus node are not increased. In other words, this experimental investigation has found no pharmacological evidence of cardiac parasympathetic denervation in these laboratory animals with experimentally induced chagasic myocarditis.

\section{RESUMO}

\section{Repostas na frequência cardíaca provocada por um agonista muscarínico em ratos com miocardite chagásica aguda e subaguda}

Administramos arecoline a ratos com miocadite chagásica induzida experimentalmente, a fim de pesquisar a sensibilidade do nodo sinusal frente a um agonista muscarínico. Ratos de 16 meses de idade foram inoculados com 200.000 parasitas de T. cruzi (variedade Y). Entre os dias 18 e 21 (estádio agudo), 8 ratos infestados e 8 ratos controle receberam arecoline por via intravenosa nas doses seguintes: 5.0, 10.0, $20.0,40.0$ e $80.0 \mu \mathrm{g} / \mathrm{kg}$. A frequência cardíaca foi registrada durante e após cada dose de arecoline. Os 8 ratos infestados restantes e mais outros 8 controles, foram submetidos a uma pesquisa similar, embora em um período de estádio subagudo da doença nos dias 60 e 70 pós inoculação. A frequência cardíaca de base dos animais estudados durante o estádio 


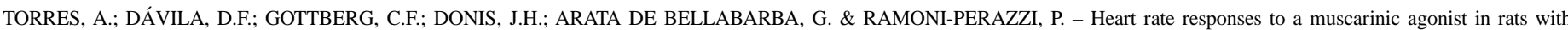
experimentally induced acute and subacute chagasic myocarditis. Rev. Inst. Med. trop. S. Paulo, 42(4): 219-224, 2000.

agudo (349 $\pm 68 \mathrm{bpm}$. Média $\pm \mathrm{SD}$ ), foi maior que a frequência dos ratos controles $(250 \pm 50 \mathrm{bpm}, \mathrm{p}<0,005)$. As alterações na frequência cardíaca foram expressadas como alterações de percentagem sobre o valor basal. Foi feita curva da dose-resposta para cada grupo de animais. Foram usadas escalas logarítmicas para simular sistematicamente as duplas doses de arecoline e as alterações de frequência induzidos. A inclinição da linha de regressão para os animais agudamente infestados $(\mathrm{r}=-0.99, \mathrm{~b}=1.78)$ não foi diferente daquela dos animais de controles $(\mathrm{r}=-0.97, \mathrm{~b}=1.61)$. Os animais infestados estudados no estádio subagudo $(\mathrm{r}=-0.99, \mathrm{~b}=1.81)$ também não apresentaram diferenças dos respectivos animais do grupo controle $(r=-0.99, b=1.26 \mathrm{NS})$. Em consequência, os nossos resultados não mostraram evidências farmacológicas de hipersensibilidade do tecido post nodo sinusal ao agonista muscarínico arecoline. Porém, o resultado indiretamente é sugestivo de que a inervação parassimpática postgangliônica do nodo sinusal dos ratos com autópsia, com comprovada miocardite chagásica, não é irreversivelmente afetada pelo Trypanosoma cruzi.

\section{REFERENCES}

1. ACQUATELLA, H.; DAVALOS, V.; CATALIOTTI, F.; RODRIGUEZ, L. \& GOMEZ, J.R. - Premature interruption of a multicentric, doubled blind, placebo-controlled study of enalapril in advanced Chagas heart disease. In: INTER-AMERICAN CONGRESS OF CARDIOLOGY, 14., Florida, 1992. Abstracts. p. 23 (Abstr. No. 74).

2. ARDELL, J.L. \& RANDALL, W.C. - Selective vagal innervation of sinoatrial and atrioventricular nodes in canine heart. Amer. J. Physiol., 251: H764- H773, 1986.

3. BESTETTI, R.B.; COUTINHO-NETO, J.; STAIBANO, L. et al. - Peripheral and coronary sinus catecholamine levels in patients with severe congestive heart failure due to Chagas' disease. Cardiology, 86: 202-206, 1995.

4. BESTETTI, R.B.; SOARES, E.G.; SALES-NETO, N.V.; ARAUJO, R.C. de \& OLIVEIRA, J.S. - The resting electrocardiogram of $T$. cruzi infected rats. Rev. Inst. Med. trop. S. Paulo, 29: 224- 229, 1987.

5. BLUEMEL, K.M.; WURSTER, R.D.; RANDALL, W.C.; DUFF, M.J. \& O'TOOLE, M.F. - Parasympathetic postganglionic pathways to the sinoatrial node. Amer. J. Physiol., 259: H1504-H1510, 1990.

6. BOJSEN-MOLLER, F. \& TRANUM-JENSEN, J. - Whole mount demonstration of cholinesterase containing nerves in the right atrial wall, nodal tissue and atrioventricular bundle of the pig heart. J. Anat., 108: 375-386, 1971.

7. BRENNER, Z. - Contribuição ao estudo da terapêutica experimental da doença de Chagas. Belo Horizonte, 1961. (Tese de Livre Docência - Fac. de Odontologia e Farmácia da Universidade de Minas Gerais).

8. CALIARI, M.V.; LANA, M. de; CALIARI, E.R. \& TAFURI, W. - Cardiac plexus of dogs experimentally infected with Trypanosoma cruzi: inflammatory lesions and quantitative studies. Rev. Soc. bras. Med. trop, 28: 13-17, 1995.

9. CAMARGOS, E.R. \& MACHADO, C.R.- Morphometric and histological analysis of the superior cervical ganglion in experimental Chagas' disease in rats. Amer. J. trop. Med. Hyg., 39: 456-462, 1988.

10. CANNON, W.B. - A law of denervation. Amer. J. Physiol, 198: 737- 750, 1932.

11. CHAPADEIRO, E.; FLORENCIO, R.F.C.; AFONSO, P.C. et al.- Neuronal counting and parasympathetic dysfunction in the hearts of chronically Trypanosoma cruzi-infected rats. Rev. Inst. Med. trop. S. Paulo, 33: 337-341, 1991.
12. DAVILA, D.F.; GOTTBERG, C.F. \& DONIS, J.H. - Vagal stimulation and cardiac slowing in acute chagasic myocarditis. J. auton. nerv. Syst., 25: 235-234, 1988.

13. DAVILA, D.F.; GOTTBERG, C.F.; TORRES, A. et al. - Cardiac sympathetic parasympathetic balance in rats with experimentally induced chagasic myocarditis. Rev. Inst. Med. trop. S. Paulo, 37: 155-159, 1995.

14. DAVILA, D.F.; INGLESSIS, G. \& DAVILA. C.A.M. - Chagas' heart disease and the autonomic nervous system. Int. J. Cardiol., 66: 123-127, 1998.

15. DE SOUZA, M.M.; ANDRADE, S.G.; BARBOSA JR., A.A. et al.- Trypanosoma cruzi strains and autonomic nervous system pathology in experimental Chagas' disease. Mem. Inst. Oswaldo Cruz, 91: 217-224, 1996.

16. DE WILDT, D.J.; KREEFTENBERG, J.G. \& NIJKAMP, F.P. - Severe impairment of cholinergic and adrenergic responsiveness in Borderella pertussis vaccinated rats. Europ. J. Pharmacol., 86: 315-316, 1986.

17. EATON, G.M.; CODY, R.J.; NUNZIATA, E. \& BINKLEY, P.F. - Early left ventricular dysfunction elicits activation of sympathetic drive and attenuation of parasympathetic tone in the paced canine model of congestive heart failure. Circulation, 92: 555$561,1995$.

18. FANBROUGH, D.M. - Control of acetylcholine receptors in skeletal muscle. Physiol. Rev., 59: 165-227, 1979.

19. FLEMMING, W.W. - A review of postjunctional supersensitivity in cardiac muscle. In: FLEMMING, W.W.; LANGER, S.Z;; GRAEFE, K.H. \& WEINER, N., ed. Neuronal and extraneuronal events in autonomic pharmacology. New York, Raven Press, 1986. p. 205-219.

20. GODFREY, K. - Simple linear regression in medical research. New Engl. J. Med., 313 1629-1636, 1985.

21. GOTTBERG, C.F.; DONIS, J.H.; TORRES, A. et al. - Heart rate changes in rats with acute chagasic myocarditis. Trans. roy. Soc. trop. Med. Hyg., 82: 99-101, 1988.

22. HANCOCK, J.C.; HOOVER, D.B. \& HOUGLAND, M.V. - Distribution of muscarinic receptors and acetylcholinesterase in the rat heart. J. auton. nerv. Syst., 13: 59-66, 1987.

23. KASEDA, S. \& ZIPES, D.P. - Supersensitivity to acetylcholine of canine sinus and AV nodes after selective parasympathetic denervation. Amer. J. Physiol., 255: H534H539, 1989.

24. KAYE, M.R. - Denervation and reinervation of the heart. In: RANDALL, W.C., ed Neural control of the heart. New York, Oxford University Press, 1977. p. 345-378.

25. KHOURY, A.M.; DAVILA, D.F.; BELLABARBA, G. et al. - Acute effects of digitalis and enalapril on the neurohormonal profile of chagasic patients with severe congestive heart failure. Int. J. Cardiol., 57: 21- 29, 1996.

26. KÖBERLE, F. - Pathogenesis of Chagas' disease In: Trypanosomiasis and Leishmaniasis with special reference to Chagas' disease. Amsterdam, Elsevier, 1974. p. 137-158. [CIBA Foundation Symposium 20 (New Series)].

27. LOFFELHOZ, K. \& PAPPANO, A.J. - The parasympathetic neuroeffector junction of the heart. Pharmacol. Rev., 37: 1-24, 1985.

28. MACHADO, C.R.S.; CALIARI, M.V.; LANA, M. \& TAFURI, W.L. - Heart autonomic innervation during the acute phase of experimental American trypanosomiasis in the dog. Amer. J. trop. Med. Hyg., 59: 492-496, 1998.

29. MARIN-NETO, J.A.; BROMBERG-MARIN, G.; PAZIN-FILHO, A. \& SIMÕES, M.V. - Cardiac autonomic impairment and early myocardial damage involving the right ventricle are independent phenomena in Chagas'disease. Int. J. Cardiol., 65: 261269, 1998. 
TORRES, A.; DÁVILA, D.F.; GOTTBERG, C.F.; DONIS, J.H.; ARATA DE BELLABARBA, G. \& RAMONI-PERAZZI, P. - Heart rate responses to a muscarinic agonist in rats with experimentally induced acute and subacute chagasic myocarditis. Rev. Inst. Med. trop. S. Paulo, 42(4): 219-224, 2000.

30. MICK, J.D.; WURSTER, R.D.; DUFF, M. et al. - Epicardial sites for vagal mediation of sinoatrial function. Amer. J. Physiol., 262: H1401-H1406, 1992.

31. PARDINI, B.J.; PATEL, K.P.; SCHNID, P.G. \& LUND, D.D. - Location, distribution and projections of intracardiac ganglion cells in the rat. J. auton. nerv. Syst., 20: 91$101,1987$.

32. PEREIRA, F.E. \& PIRES, J.G. - Chronotropic responses to acetylcholine in atria of mice chronically infected with Y and CL strains of Trypanosoma cruzi. Braz. J. med. biol. Res., 21: 1019-1021, 1988.

33. RANDALL, W.C. \& ARDELL, J.L. - Functional Anatomy of the cardiac efferent innervation. In: KULBERTUS, H.E. \& FRANCK, G., ed. Neurocardiology. New York, Futura Publ. Co., 1988. p. 3-24.

34. RANDALL, W.C.; ARDELL, L.L.; WURSTER, R.D. \& MILOSAVLJEVIC, M. - Vagal postganglionic innervation of the canine sinoatrial node. J. auton. nerv. Syst., 20: 13-23, 1987.
35. SCORZA, C. \& SCORZA, J.V. - Acute myocarditis in rats inoculated with Trypanosoma cruzi. Study of animals sacrificed between the fourth and twenty-ninth days after infection. Rev. Inst. Med. trop. S. Paulo, 14: 171-177, 1972.

36. TAFURI, W.L. - Pathogenesis of lesions of the autonomic nervous system of the mouse in experimental acute Chagas‘ disease. Amer. J. trop. Med. Hyg., 19: 405-417, 1970.

37. TANOWITZ, H.B.; DAVIES, P. \& WITTNER, M. - Alterations in acetylcholine receptors in experimental Chagas' disease. J. infect. Dis., 147: 460-466, 1983.

38. TORRES, A.; DAVILA, D.F.; GOTTBERG, C.F. et al. - Heart rate responses to intravenous serotonin in rats with acute chagasic myocarditis. Braz. J. med. biol. Res., 29: 817 $822,1996$.

39. WONG, W.C.; TAN, C.K.; SINGH, M. \& YICK, T.Y. - Ultrastructure of murine cardiac ganglia in experimental Chagas' disease. Histol. Histopath., 7: 371-378, 1992.

Received: 29 March 1999

Accepted: 17 March 2000 